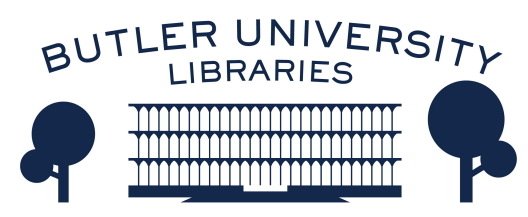

Journal of Hindu-Christian Studies

Volume 2

Article 4

January 1989

\title{
The Prospect for Hindu-Christian Interaction
}

Margaret Chatterjee

Follow this and additional works at: https://digitalcommons.butler.edu/jhcs

Part of the Religion Commons

\section{Recommended Citation}

Chatterjee, Margaret (1989) "The Prospect for Hindu-Christian Interaction," Journal of Hindu-Christian Studies: Vol. 2, Article 4.

Available at: https://doi.org/10.7825/2164-6279.1013

The Journal of Hindu-Christian Studies is a publication of the Society for Hindu-Christian Studies. The digital version is made available by Digital Commons @ Butler University. For questions about the Journal or the Society, please contact cbauman@butler.edu. For more information about Digital Commons @ Butler University, please contact digitalscholarship@butler.edu. 
in India. At the time of his death Dick Taylor was hard at work to finish his long awaited book on Ashrams, an update on the ashram movement in India. Molly, Dick's wife, is now at work finishing the book.

Dick served on and contributed significantly to the work of several Church and other Christian committees and commissions, notably one on the Churches' fulfilment of responsibility in society, and the other which did a national survey of theological education in India. Indeed, Dick Taylor's contribution to Christian socio-economic and cultural thought and action in India is exceptional and it will take much study and space to fully gauge the value of his work. His sudden passing leaves a vacuum in these fields.

David C. Scott

The United Theological College

Bangalore, India

\section{The Prospect for Hindu- Christian Interaction Margaret Chatterjee Director \\ Indian Institute of Advanced Study, Shimla, India}

I take as a starting point the last sentence of the Editorial in Vol. I of the new Bulletin: "With a few notable exceptions...contemporary Hindu thinkers do not seem to be engaged with Christianity in the way their predecessors were at the turn of the century (e.g. Roy, Sen, Dayananda and Radhakrishnan)". This is a very insightful observation and it is worth dwelling on. Let us begin from the "Christian side" first. What considerations are encouraging some Christians to "take an interest" in Hinduism. Listing some of these may be convenient although probably too schematic, for combinations of the following are often to be found:

1. The "colonial cloud" having passed over, the way is free for Hindus and Christians to meet on equal terms. Some Christians, especially those with long connections with India, find in this an opportunity for closer contact. The religious component may sometimes be a part of this contact.

2. Indian Christians still feel the need to inculturate their faith. This cannot be done unless Hinduism is studied in the seminaries, liturgical innovations are made, and "new Christian's are made to feel at home". Why parallel efforts to inculturate vis à vis Islam or Sikhism are not made so seriously is worth exploring.

3. People in some western countries show a new interest in meditation, whether of the Buddhist or Hindu varieties. Some churches/spiritual instructors/ are seeking to adopt some of the exercises/practices in a Christian context. Probably even more are experimenting with meditative techniques outside any such "religious" setting. What this involves needs to be looked into. Is meditation necessarily a species of prayer? Can it be extracted from its cultural package?

4. A few rare souls, through some kind of mystic route, seem to have gained entry into Hindu religious experience of a particular kind (whether Advaitin, Vaishnava, etc.). Such cases are no doubt exceptional.

5. A few theologians, who are sensitive to what strikes them as the inappropriateness of the "unique" claims made by certain types of Christian theology, are seeking to get over this in diverse ways including selective appropriation/experiential ingress/intellectual formulation, etc.

6. Religious Studies departments (outside India) provide a cognitive base for further exploration and contact. Comparative studies involve both scholarly work and "dialogue".

Let us now see how each point fares, so to say, from the Hindu point of view.

1. Even though Hindus and Christians meet on equal terms, thanks to the franchise, absence of the colonial power, etc. the original parallel presence of colonizers and missionaries is something that lives on in Hindu memory. The "inculturation" of Christianity in India has been greatly accelerated in recent years. This notwithstanding, from a Hindu point of view the Indian Christian has to validate himself first of all as a nationalist. Hindu activists these days are revivalists rather than reformers (using an earlier distinction). The swadharma idea, moreover, operates to discourage basic curiosity about what Christians believe. I have gone into this elsewhere. 1

2. Returning the "compliment" of assimilation (which is what inculturation is rather like) does not bring the Christian any closer. The insider/outsider distinction prevails. Since Hinduism is not institutionalized, there is nothing parallel to the study of Hinduism by Christian seminarians to be found among Hindus.

3. There is likewise nothing parallel to this point either.

4. Here again there is scarcely anything parallel to what a few exceptional (mainly) Catholic "religieux" have been able to accomplish. "Conversions" would not serve as examples.

5. The interest in Christianity showed by some of the nineteenth and early twentieth century reformers has not continued into the twentieth century. The question of formulating a "theology" in the Hindu context does not arise today.

6. "Religious Studies" has scarcely got off the ground as a subject for academic studies in Indian Universities. The reasons for this can be spelled out.

The above very brief comments do not do more than present a viewpoint based on contemporary experience, an experience of feeling the pulse, as it were, of the situation in India just now. The idea is by no means to discourage the studies planned. There is all the more need for such a project, precisely because Hindu thinkers today are "not engaged with Christianity in the way their predecessors were".

\section{Notes}

1. Vide my The Religious Spectrum, Allied publishers Private Limited, New Delhi, 1984.

\section{The Scope of Dialogue Anand Amaladass}

Institute of Philosophy and Culture, Madras, India

India has been the land of intense curiosity for others for many centuries and continues to be so. One can trace the history of relationship between India and the outside world as a fruitful study to gain some insight into the Indian attitude towards outsiders. In the first issue of this Bulletin the editor presented a succinct survey of dialogical movements in Indian History. Obviously in a brief essay of this type one cannot expect a comprehensive report covering all the historical events and persons who have contributed to the dialogical movements between the Hindu and the Christian world. In fact some of our perceptive readers have pointed out some omissions and we appreciate their keen interest in this venture by responding to us enthusiastically to the format and the content of the first Bulletin.

In fact the present issue contains a review of Wilhelm Halbfass' book India and Europe and we intend to draw the 